\title{
ReishiMax, mushroom based dietary supplement, inhibits adipocyte differentiation, stimulates glucose uptake and activates AMPK
}

\author{
Anita Thyagarajan-Sahu', Brandon Lane ${ }^{1}$ and Daniel Sliva ${ }^{1,2,3^{*}}$
}

\begin{abstract}
Background: Obesity is a health hazard which is closely associated with various complications including insulin resistance, hypertension, dyslipidemia, atherosclerosis, type 2 diabetes and cancer. In spite of numerous preclinical and clinical interventions, the prevalence of obesity and its related disorders are on the rise demanding an urgent need for exploring novel therapeutic agents that can regulate adipogenesis. In the present study, we evaluated whether a dietary supplement ReishiMax (RM), containing triterpenes and polysaccharides extracted from medicinal mushroom Ganoderma lucidum, affects adipocyte differentiation and glucose uptake in 3T3-L1 cells.

Methods: 3T3-L1 pre-adipocytes were differentiated into adipocytes and treated with RM (0-300 $\mu \mathrm{g} / \mathrm{ml})$. Adipocyte differentiation/lipid uptake was evaluated by oil red $\mathrm{O}$ staining and triglyceride and glycerol concentrations were determined. Gene expression was evaluated by semi-quantitative RT-PCR and Western blot analysis. Glucose uptake was determined with $\left[{ }^{3} \mathrm{H}\right]$-glucose.

Results: RM inhibited adipocyte differentiation through the suppresion of expression of adipogenic transcription factors peroxisome proliferator-activated receptor- $\gamma$ (PPAR- $\gamma$ ), sterol regulatory element binding element protein-1c (SREBP-1C) and CCAAT/enhancer binding protein- $\alpha$ (C/EBP- $\alpha$ ). RM also suppressed expression of enzymes and proteins responsible for lipid synthesis, transport and storage: fatty acid synthase (FAS), acyl-CoA synthetase-1 (ACS1), fatty acid binding protein-4 (FABP4), fatty acid transport protein-1 (FATP1) and perilipin. RM induced AMPactivated protein kinase (AMPK) and increased glucose uptake by adipocytes.
\end{abstract}

Conclusion: Our study suggests that RM can control adipocyte differentiation and glucose uptake. The health benefits of ReishiMax warrant further clinical studies.

\section{Background}

Obesity is increasing at an alarming rate in the developed as well as developing countries [1]. In the United States obesity is increasing not only in adults but also in children [2]. Among various factors which contribute to the likelihood of death, obesity has escalated the chances of death by $20 \%$ and it has lately surpassed smoking as the number one cause of death in the US [3,4]. According to survey carried out in 2007-2008 by the National Health and Nutrition Examination Survey (NHANES) nearly $32.2 \%$ of adult men and $35.5 \%$ of adult women were obese [5]. There are numerous epidemiological

\footnotetext{
* Correspondence: dsliva@iuhealth.org

'Cancer Research Laboratory, Methodist Research Institute, Indiana University Health, 1800 N Capitol Ave, E504, Indianapolis, IN 46202, USA

Full list of author information is available at the end of the article
}

studies indicating that obese humans are at elevated risk of developing non-insulin-dependent (type 2) diabetes mellitus, hypertension, cancer and atherosclerosis $[3,6,7]$.

There are several lines of evidence to show that obesity triggers the dysregulation of the endocrine function of the adipose tissue $[8,9]$. This suggests that adipose tissue is no longer considered to be an inert tissue solely responsible for energy store, instead is recognized as a major secretory organ, releasing a variety of adipocytokines such as adiponectin, leptin, resitin and visfatin [10]. These adipocytokines provide the link between obesity, insulin resistance and inflammatory disorders $[10,11]$. Differentiation of fibroblasts into adipose tissue requires chronological changes in the expression of numerous genes [12-14]. The initial events are orchestrated by several transcription factors, CCAAT/

\section{C) Bïomed Central}


enhancer binding protein- $\alpha(\mathrm{C} / \mathrm{EBP}-\alpha)$, sterol regulatory element binding protein-1c (SREBP-1c) and peroxisome proliferators-activator receptor- $\gamma$ (PPAR- $\gamma$ ). PPAR- $\gamma$ is involved in the regulation of genes controlling lipid uptake and is also a "master" regulator that triggers the complete process of adipogenesis [15]. These proteins participate in a transcriptional cascade that controls the expression of a number of genes which are essential in the lipid accumulation in adipocytes during the process of differentiation $[16,17]$. Sterol regulatory element binding proteins (SREBPs) are transcription factors that have been associated with lipogenesis regulating the expression of acetyl-CoA carboxylase (ACC), fatty acid synthase (FAS) and acyl-CoA synthase (ACS) [18]. The expression of the above factors alone cannot promote differentiation of pre-adipocytes, but when co-expressed with on adipocytes expressing PPAR- $\gamma$ cell differentiation is enhanced [19-22]. Differentiated adipocytes also secrete cytokines tumor necrosis factor- $\alpha$ (TNF- $\alpha)$, and interleukins (IL-6 and IL-1 $\beta$ ) which are major regulators of adipocyte metabolism [23]. Hence, adipose tissue plays an important role in homeostasis of energy and is emerging as a major drug target for obesity and obesity mediated metabolic disorders [24-26]. Recent studies have shown a strong link between obesity and type 2 diabetes and insulin resistance [27]. Therefore, various pharmacologic agents (e.g. thiazolidinediones and metformin) are used to enhance insulin sensitivity [28]. A main mode of action of a common type 2 diabetes drug, metformin is an activation of AMP-activated protein kinase (AMPK) in skeletal muscles and hepatocytes [29].

Medicinal mushroom Ganoderma lucidum, which is well recognized by the Traditional Chinese Medicine (TCM) [30-33], is globally used as a popular dietary supplement. We have previously demonstrated that ReishiMax (RM), a dietary supplement containing triterpenes and polysaccharides extracted from medicinal mushroom G. lucidum, is effective in inhibiting the proliferation, invasive behavior and angiogenesis in different cancer models [34-39]. In the present study we evaluated the effect of RM on the adipocyte differentiation and glucose uptake in adipocytes. Our data suggest that RM can be used as a natural agent to control obesity and associated type 2 diabetes.

\section{Methods \\ Materials}

3T3-L1 preadipocytes, Dulbecco's modified Eagle's (DMEM) medium, Trypsin-EDTA were obtained from American Type Culture Collection (ATCC, Manassas, VA, USA). Fetal calf serum (FCS) was purchased from Colorado serum company (Denver, CO, USA). Fetal bovine serum (FBS), Penicillin and streptomycin were obtained from Invitrogen (Carlsbad, CA, USA). Insulin
(INS), dexamethasone (DEX), isobutyl-methylxanthine (IBMX), oil red $\mathrm{O}$, isopropanol and dimethyl sulphoxide (DMSO) were received from Sigma (St. Louis, MO, USA). Dulbecco's Phosphate Buffered Saline (DPBS) was obtained from Lonza (Walkerville, MD, USA). ReishiMax (RM) was supplied by Pharmanex (Provo, UT). RM is a standardized Ganoderma lucidum extract containing $6 \%$ triterpenes and $13.5 \%$ polysaccharides and the extraction procedure was previously described [40]. RM stock solution was prepared in DMSO.

\section{Cell culture and adipocyte differentiation}

3T3-L1 preadipocytes were maintained in DMEM, supplemented with $10 \%$ FCS, penicillin (100 units $/ \mathrm{ml})$ and streptomycin $(100 \mu \mathrm{g} / \mathrm{ml})$ at $37^{\circ} \mathrm{C}$ in humidified atmosphere with $5 \% \mathrm{CO}_{2}$. Cell differentiation was initiated as previously described [41]. Briefly, cells were grown in 6 well plates until 2 days post-confluence. Differentiation was induced by adding $1 \mu \mathrm{g} / \mathrm{ml}$ of insulin, $0.25 \mu \mathrm{M}$ of dexamethasone and $0.5 \mathrm{mM}$ isobutyl-methylxanthine in DMEM with $10 \%$ FBS. The INS-DEX-IBMX medium was replaced after 2 days to medium with insulin alone for another 2 days after which they were supplemented with $10 \%$ FBS every other day thereafter. To evaluate the role of RM on lipid accumulation 3T3-L1 cells were treated with $0-300 \mu \mathrm{g} / \mathrm{ml}$ of RM along with the differentiation medium containing INS-DEX-IBMX. The differentiated cells were used after 9 days of initiating the differentiation. All cells, including controls cells, were treated with the same concentration of DMSO (0.3\%).

\section{Oil red $O$ staining}

The lipids accumulated in the adipocytes were quantified after staining the 3T3-L1 cells with oil red O staining [42]. Briefly, after differentiation the cells were fixed with $10 \%$ formalin for 1 hour and washed with $60 \%$ isopropanol. After air drying the plates were stained with oil red $\mathrm{O}$ working solution (6 parts of $0.35 \%$ stock Oil red $\mathrm{O}$ and 4 parts of distilled water) for $30 \mathrm{~min}$ and rinsed with water. Images were obtained using an Olympus CX40 microscope (Center Valley, PA, USA) at 20x magnification, picture frame software from Optronics (Goleta, CA, USA) was used to obtain all images at similar intensities. To quantify the amount lipid uptake, the oil red O stain was eluted by adding $100 \%$ iso-propanol for $10 \mathrm{~min}$, and the absorbance measured at 510 $\mathrm{nm}$ on a microplate spectrophotometer using the Gen5 software by BioTek Instruments (Winooski, VT, USA).

\section{Analysis of triglycerides (TG)}

During differentiation 3T3-L1 cells were treated with $\mathrm{RM}(0-300 \mu \mathrm{g} / \mathrm{ml})$. Subsequently the cells were rinsed with PBS, scrapped and collected [43,44]. Triglycerides (TG) were quantified in the extract according to 
manufacture's protocol (Triglyceride GPO-Trinder Kit, St. Louis, MO, USA).

\section{Lipolysis determination}

Lipolysis was determined as the amount of free endogenous glycerol released after RM treatment $(0-300 \mu \mathrm{g} /$ $\mathrm{ml}$ ) into the conditioned medium. Glycerol concentration was measured using the GPO-Trinder assay kit (Sigma, St Louis, MO, USA), according manufacture's protocol.

\section{Isolation and analysis of RNA}

Total RNAs were isolated from 3T3-L1 adipocytes using RNeasy Mini Kit (Qiagen, Valencia, CA) after the cells were treated with RM $(0-300 \mathrm{ug} / \mathrm{ml})$ during the differentiation process. Each sample of first-strand cDNA was synthesized from $2 \mu \mathrm{g}$ total RNA using SuperScript III first-strand synthesis system (Invitrogen, Carlsbad, CA, USA) according to manufacturer's protocol using DNA thermal cycler 480 (Perkin Elmer, Emeryville, CA, USA). The cDNA was amplified using Platinum PCR master mix (Invitrogen, Carlsbad, CA) using the following forward and reverse primers: PPAR- $\gamma$ (NM_011146.2) forward primer 5'-TTT-TCA-AGG-GTG-CCA-GTT-TC-3' and reverse primer 5'-AAT-CCT-TGG-CCC-TCTGAG-AT-3' (PCR product 197 bp); SREBP-1c (NM_011480.2) forward primer 5'-TGT-TGG-CATCCT-GCT-ATC-TG-3' and reverse primer 5'-AGGGAA-AGC-TTT-GGG-GTC-TA-3' (PCR product 189 bp); C/EBP- $\alpha$ (NM_007678) forward primer 5'-TTACAA-CAG-GCC-AGG-TTT-CC-3' and reverse primer 5'-GGC-TGG-CGA-CAT-ACA-GTA-CA-3' (PCR product 189 bp); FABP4 (NM_024406) forward primer 5'TCA-CCT-GGA-AGA-CAG-CTC-CT-3' and reverse primer 5'-AAT-CCC-CAT-TTA-CGC-TGA-TG-3' (PCR product $162 \mathrm{bP}$ ); FATP1 (NM_011977) forward primer 5'-TGC-CTC-TGC-CTT-GAT-CTT-TT-3' and reverse primer 5'-GGA-ACC-GTG-GAT-GAA-CCT-AA-3' (PCR product $161 \mathrm{bp}$ ); FAS (NM_007988.3) forward primer 5'-TTG-CTG-GCA-CTA-CAG-AAT-GC-3' and reverse primer 5'-AAC-AGC-CTC-AGA-GCG-ACAAT-3' (PCR product $192 \mathrm{bp}$ ); ACS1 (NM_007981.3) forward primer 5'-CAA-CCC-AGA-ACC-ATG-GAA-GT-3' and reverse primer 5'-CTG-ACT-GCA-TGG-AGAGGT-CA-3' (PCR product 195 bp); perillipin (NM_175640.1) forward primer 5'-AAG-GAT-CCTGCA-CCT-CAC-AC-3' and reverse primer 5'-CCTCTG-CTG-AAG-GGT-TAT-CG-3' (PCR product 191 bp); LPL (NM_008509.2) forward primer 5'-TCC-AAGGAA-GCC-TTT-GAG-AA-3' and reverse primer 5'CCA-TCC-TCA-GTC-CCA-GAA-AA-3' (PCR product 186 bp); $\beta$-actin (NM_007393.2) forward primer 5'AGC-CAT-GTA-CGT-AGC-CAT-CC-3' and reverse 5'TCC-CTC-TCA-GCT-GTG-GTG-GTG-AA-3' (PCR product $211 \mathrm{bp}$ ). PCR reactions were performed for 30 cycles, unless otherwise indicated, to identify the linear range for PCR. PCR products were separated on a $1.5 \%$ agarose gel and photographed. The PCR products were quantified using Flourchem software (Alpha Innotech, San Leandro, CA).

\section{Glucose uptake}

Glucose uptake was analyzed by measuring the uptake of 2-deoxy-D- $\left[{ }^{3} \mathrm{H}\right]$ glucose as described previously $[45,46]$. Briefly, confluent 3T3-L1 adipocytes grown in 12 well plates were rinsed twice with serum free no-glucose DMEM medium, and incubated with $2 \mathrm{ml}$ of the same medium in incubator with $8 \% \mathrm{CO}_{2}$ at $37^{\circ} \mathrm{C}$ for 2 hours. The cells were washed with Krebs-Ringer-Hepes (KRP) buffer and incubated in $0.9 \mathrm{ml}$ of this buffer at $37^{\circ} \mathrm{C}$ for 30 minutes. Insulin $(0-200 \mathrm{nM})$ and $\mathrm{RM}(0-200$ $\mu \mathrm{g} / \mathrm{ml}$ ) were added in the last 20 minutes. Glucose uptake was initiated by adding $0.1 \mathrm{ml}$ of KRP buffer, 5 $\mu \mathrm{Ci} / \mathrm{ml}$ of 2-deoxy-D- $\left[{ }^{3} \mathrm{H}\right]$-glucose and $1 \mathrm{mM}$ of deoxyglucose (final concentration). After $10 \mathrm{~min}$, the glucose uptake was terminated by washing the cells thrice with cold PBS. The cells were lysed with $0.7 \mathrm{ml}$ of $1 \%$ Triton $\mathrm{X}-100$ at $37^{\circ} \mathrm{C}$ for 20 minutes, and the radioactive glucose uptake was determined by the scintillation counter (Beckman Inst. Inc, Fullerton, CA, USA).

\section{Western Blot analysis}

3T3-L1 pre-adipocytes were treated with RM $(0-300 \mu \mathrm{g} /$ $\mathrm{ml}$ ) during the process of differentiation as indicated in the text (perilipin analysis) and whole cell extracts prepared as previously described [47]. Alternatively, differentiated adipocytes were incubated in serum free media for 2 hours and subsequently stimulated with RM (0$100 \mu \mathrm{g} / \mathrm{ml})$ or Insulin $(0-200 \mathrm{nM})$ for 30 minutes (AMPK analysis). Equal amounts of cellular proteins (30 $\mu \mathrm{g} / \mathrm{lane})$ were separated on NuPAGE $12 \%$ or $4-12 \%$ BisTris gel (Invitrogen, Carlsbad, CA, USA), and transferred to a PVDF membrane (Millipore, Bedford, MA, USA) using XCell II blot module (Invitrogen). The protein expression was detected with the corresponding primary antibodies for anti-perilipin, anti-phosphoAMPK $\alpha$ (Thr-172), anti-AMPK (Cell Signaling, Beverly, MA, USA) and anti- $\beta$-actin antibody (Santa Cruz Biotechnology, Santa Cruz, CA, USA). Protein expression was visualized using the ECL Western Blotting Detection System (Santa Cruz Biotechnology). Densitometric analysis of the bands for the expression of protein was done with Flourchem software (Alpha Innotech, San Leandro, CA).

\section{Statistical Analysis}

Data are represented as mean \pm S.D and were analyzed using SigmaPlot 11.2 (Systat Software Inc, San Jose, CA, 
USA). The differences between the groups were analyzed by one way ANOVA with Bonferroni multiple comparison post-hoc test.

\section{Results \\ Effect of RM on lipid accumulation, triglyceride uptake and glycerol accumulation}

To evaluate whether RM affects the lipid uptake in adipocytes, we analyzed the changes in the amount of triglycerides and glycerol after inducing adipocyte differentiation. Adipocytes accumulate lipids by two major mechanisms either by de novo lipogenesis from non-lipid precursors or by uptake of fatty acids from the plasma [48]. To evaluate the effect of RM on lipid uptake by adipocytes, cells were treated with RM (0-300 $\mu \mathrm{g} / \mathrm{ml}$ ) in the presence of the differentiation mix of 1 $\mu \mathrm{g} / \mathrm{ml}$ of INS, $0.25 \mu \mathrm{M}$ of DEX and $0.5 \mathrm{mM}$ IBMX in DMEM with $10 \%$ FBS as described in Materials and Methods. As seen in Figure 1A, differentiation of preadipocytes (a) to adipocytes (b) was associated with the increased oil red $\mathrm{O}$ positive cells, whereas $\mathrm{RM}$ treatment markedly suppressed lipid accumulation in differentiated adipocytes (Figure 1A b-e, Figure 1B). Since most reserves of energy in the human body are stored in adipocytes in the form of triacylglycerol (TAG) [12], we assessed the amount of triglycerides (TG) and glycerol released due to lipolysis from adipocytes treated with RM. As expected, TG and glycerol levels in adipocytes were significantly decreased in a dose response manner after RM treatment (Figure $1 \mathrm{C}$ and Figure 1D).

\section{RM inhibits the expression of transcription factors controlling lipogenic pathways}

Next we examined the role of transcription factors involved in adipocyte differentiation. The effect of RM on the expression of PPAR- $\gamma$, SREBP-1c and C/EBP- $\alpha$ was evaluated by RT-PCR. As seen in Figure 2, differentiated adipocytes had substantially increased levels of the PPAR- $\gamma$, SREBP-1c and C/EBP- $\alpha$ compared to preadipocytes. Moreover, treatment of pre-adipocytes with ReishiMax (0-300 ug/ml) decreased the expression of PPAR- $\gamma$ (Figure 2A), SREBP-1c (Figure 2B) and C/ EBP- $\alpha$ (Figure $2 \mathrm{C}$ ) in a dose dependent manner, suggesting that the RM inhibits adipocyte lipogenesis through PPAR $-\gamma$, SREBP $-1 \mathrm{c}$ and C/EBP $-\alpha$ regulated genes.

\section{RM suppresses expression of proteins regulating synthesis and transport of fatty acids}

As shown above, RM treatment inhibits the expression of PPAR $-\gamma$, SREBP $-1 \mathrm{c}$ and C/EBP- $\alpha$ which regulate genes responsible for the synthesis and transport of fatty acids. Thus, we determined whether RM also suppresses expression of the fatty acid synthesis enzymes (FAS and
ACS1) and proteins involved in the transport of fatty acids (FABP4 and FATP1). 3T3-L1 cells were differentiated and treated with RM $(0-300 \mathrm{ug} / \mathrm{ml})$ and expression of FAS, ACS1, FABP4 and FATP1 evaluated by RT-PCR as described in Materials and Methods. As seen in Figure 3A and 3B, RM treatment significantly inhibited the expression of FAS and ACS1 in a doseresponse manner. In addition, RM treatment significantly inhibited the expression of FABP4 (Figure 4A), and FATP1 (Figure 4B), Therefore our data suggest that RM suppresses expression of proteins involved in lipid synthesis and lipid transport.

\section{Effect of RM on the expression of perilipin and LPL}

During the process of differentiation the adipocytes accumulated lipid in the form of lipid droplets. These lipid droplets are protected by different fat specific proteins including perilipin. Since RM treatment decreases the expression of the transcription factors, enzymes and transporter proteins involved in the synthesis and transport of fatty acids, we were interested to further determine whether RM treatment could also modulate the expression of perilipin. As seen in Figure 5, differentiation from preadipocytes to adipocytes markedly increased the levels of perilipin, whereas RM suppressed dose-dependently its expression at mRNA (Figure 5A) as well as protein (Figure $5 \mathrm{~B}$ ) levels, respectively. Lipid droplets are hydrolyzed by lipoprotein lipase (LPL) [49] which expression is controlled by SREBP-1c during adipocyte differentiation [50]. Since RM inhibits production of glycerol and SREBP-1c (Figure 1D, 2B), we evaluated the effect of RM (0-300 ug/ml) on LPL expression by RT-PCR during the adipocyte differentiation. However, RM did not show any effect on LPL expression (not shown).

\section{RM induces AMPK and glucose uptake in adipocytes}

The activation/phosphorylation of AMPK is crucial for the treatment of diabetes and metabolic syndrome [51]. To evaluate whether RM activates AMPK, 3T3-L1 adipocytes were treated with $\mathrm{RM}(0,50,100 \mu \mathrm{g} / \mathrm{ml})$ or insulin (100, $200 \mathrm{nM})$ for 30 minutes and phosphorylation of AMPK determined by Western blot analysis with anti-pAMPK-Thr172 antibody. As seen in Figure 6A, $\mathrm{RM}$ induced phosphorylation of AMPK in a dose response manner and this effect was comparable to the insulin treatment. Because AMPK can function as an energy sensor and also stimulates glucose uptake $[52,53]$, we evaluated whether RM stimulates glucose uptake in differentiated adipocytes. As expected, RM markedly induced glucose uptake in adipocytes in a dose response manner (Figure 6B), confirming that RMinduced phosphorylation of AMPK results in the glucose uptake. 
A

\section{PA}

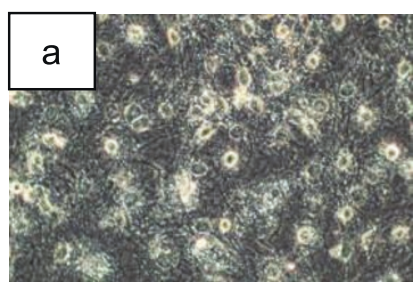

A

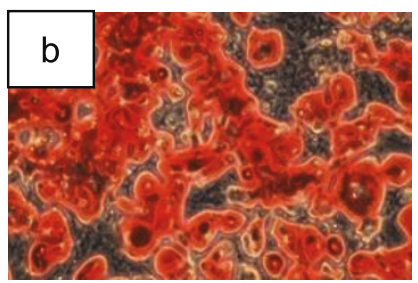

A/RM100

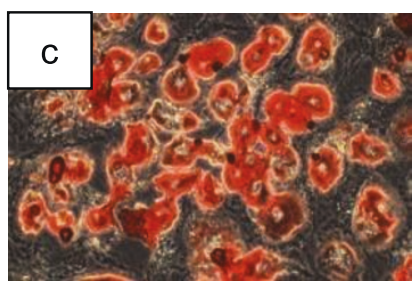

A/RM200

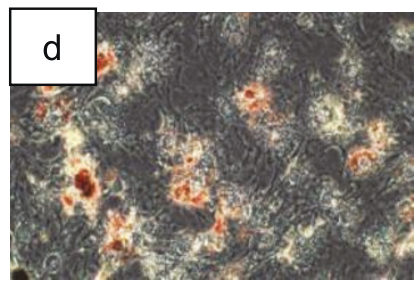

A/RM300

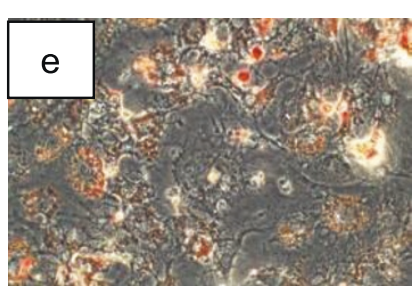

B

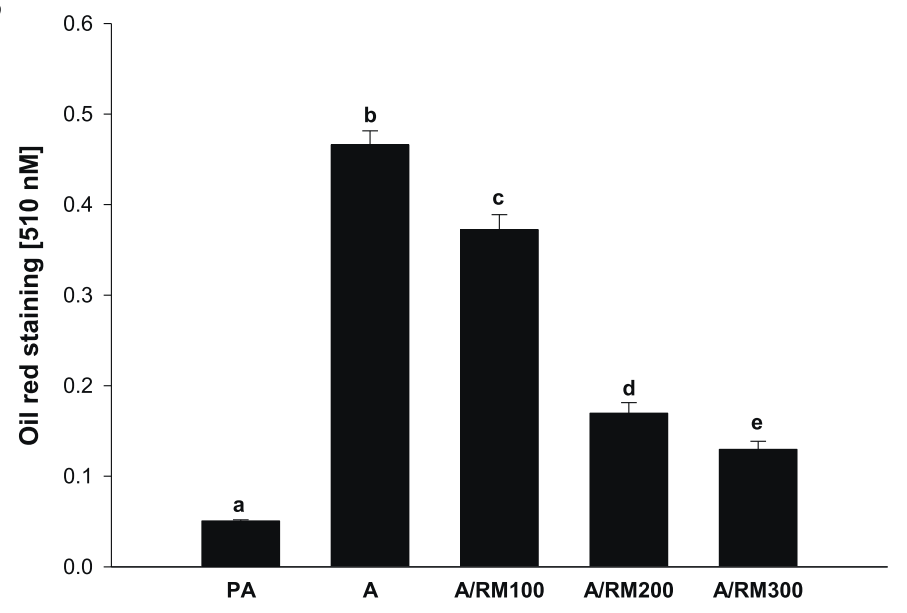

C

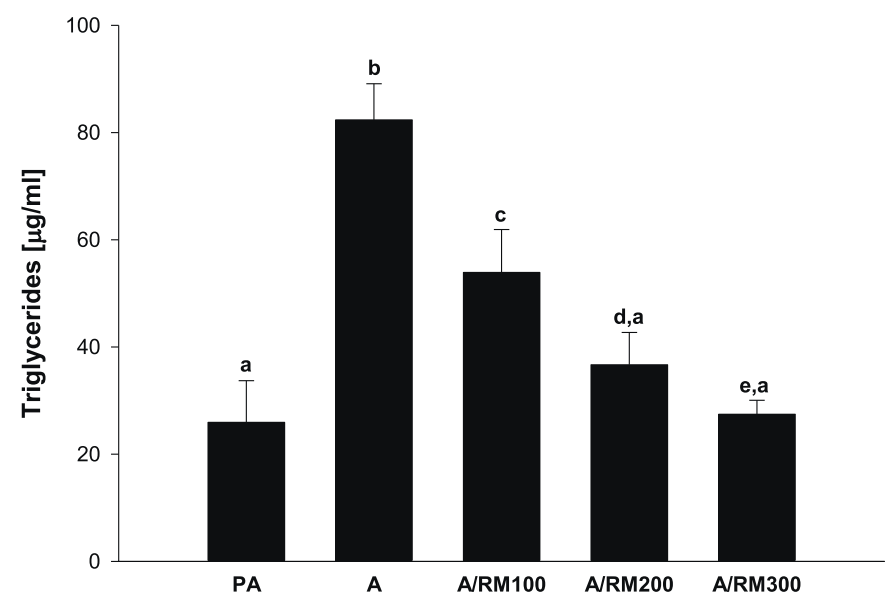

D

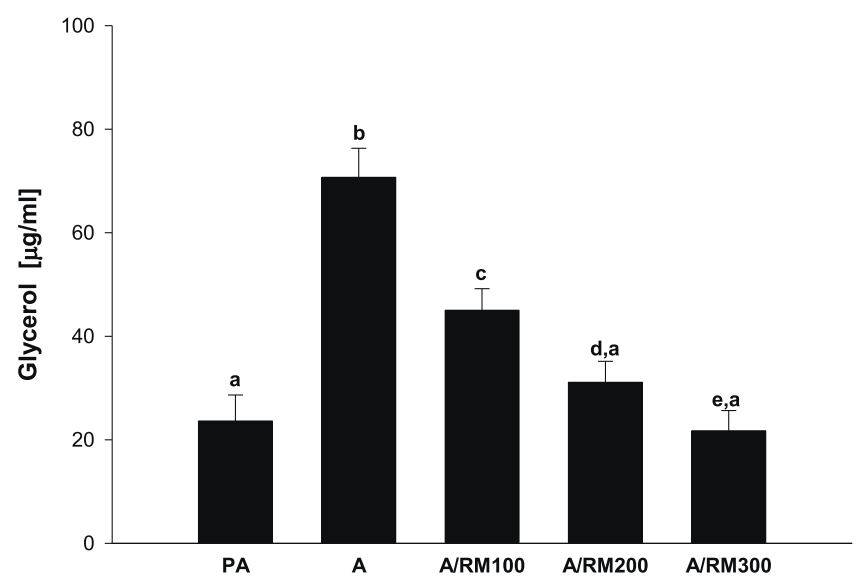

Figure 1 Effect of RM on lipid accumulation during differentiation. 3T3-L1 pre-adipocytes 2 days after confluence were induced to differentiate in the presence of RM (0-300 $\mathrm{\mu g} / \mathrm{ml})$. At day 9 adipocytes were stained with Oil red $\mathrm{O}$ as shown in Figure 1A. (a) pre-adipocytes, (b)

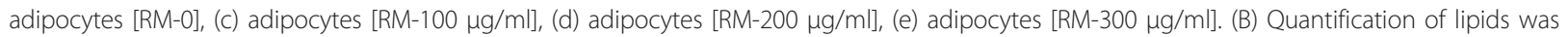
measured after eluting with isopropanol and reading the absorbance at $510 \mathrm{~nm}$. (C) triglyceride and (D) glycerol concentration was determined as described in Materials and Methods. Each experiment was performed three times in triplicates. Results are depicted as mean \pm SD, statistical significance was calculated (letters that differ indicate, $p \leq 0.05$ ). For our studies we used cells up to passage twelve. 
A

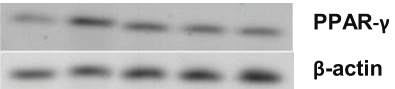

PA A A A A

- $\quad-100200300 \quad \mathrm{RM} \mu \mathrm{g} / \mathrm{ml}$

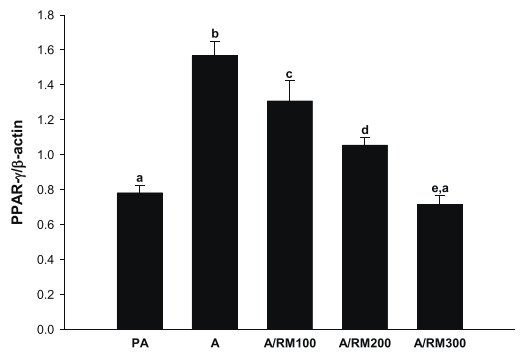

B
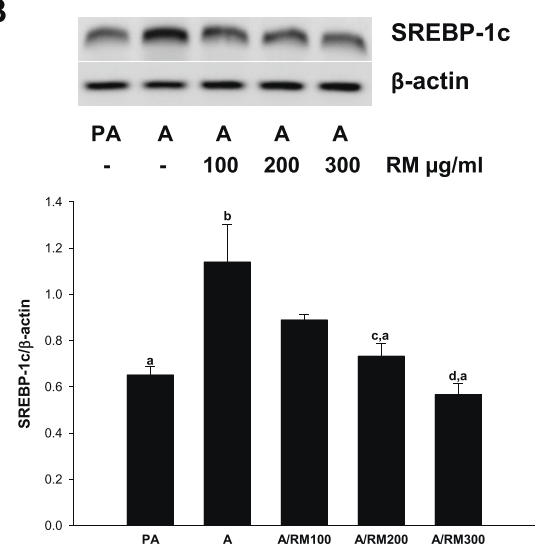

C

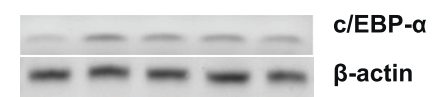

PA A A A A

- $\quad 100200300 \quad \mathrm{RM} \mu \mathrm{g} / \mathrm{ml}$

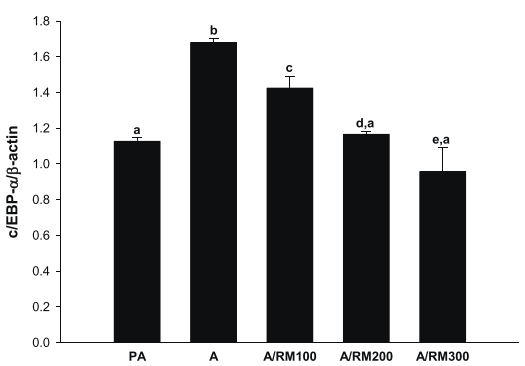

Figure 2 Effect of RM on adipogenic transcription factors. 3T3-L1 pre-adipocytes 2 days after confluence were induced to differentiate in the presence of RM (0-300 $\mu \mathrm{g} / \mathrm{ml})$. At day 9 adipocytes RNA was isolated and RT-PCR for mRNA expression of (A) PPAR- $\gamma$, (B) SREBP-1 and (C) C/EBP$\alpha$ was performed as described in Materials and Methods. Ratio is calculated against $\beta$-actin represented as arbitary units of integrated density value (IDV). Each experiment was repeated twice in duplicate and results are depicted as mean \pm SD, statistical significance was calculated (letters that differ indicate, $p \leq 0.05$ ). 
A

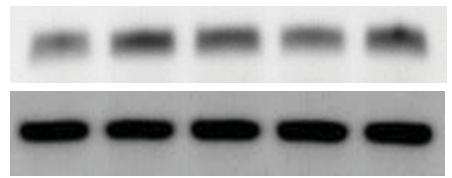

FAS

\section{PA A A A A \\ - $\quad 100200300 \mathrm{RM} \mu \mathrm{g} / \mathrm{ml}$}

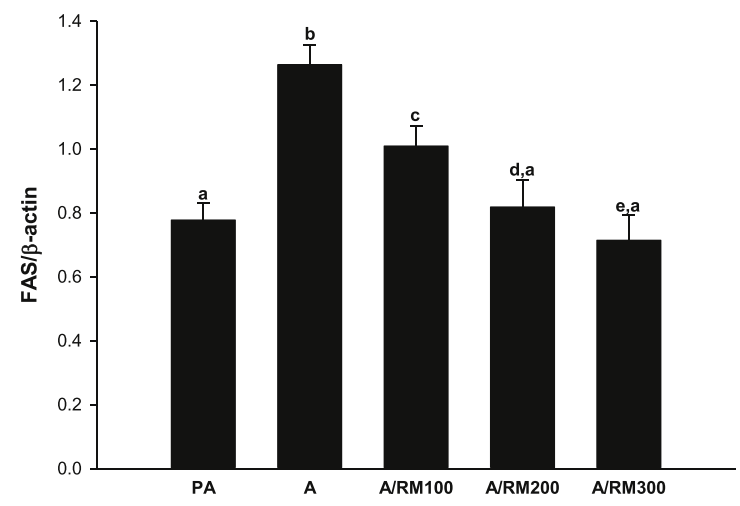

B
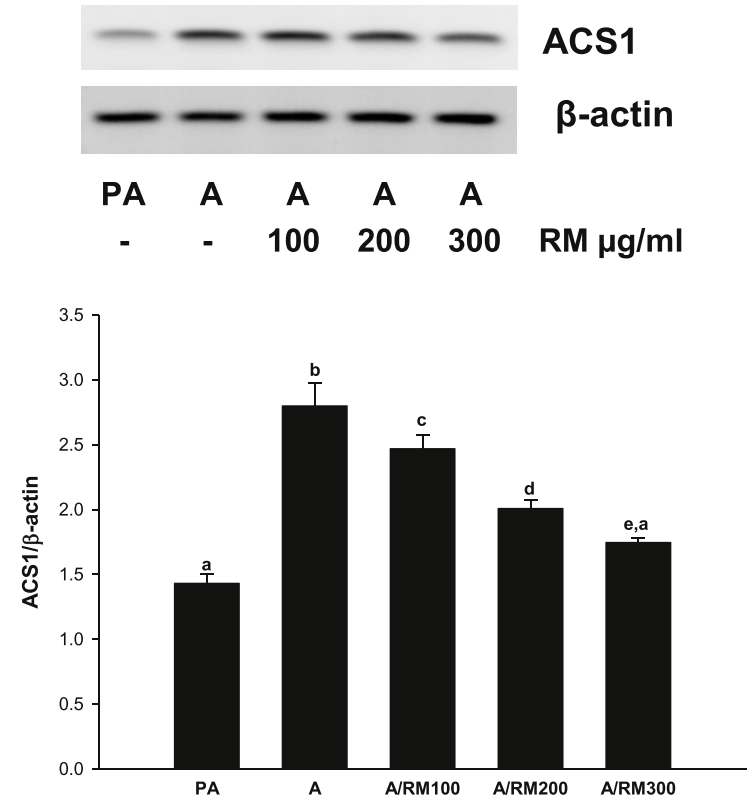

Figure 3 Effect of RM on FAS and ACS1. 3T3-L1 pre-adipocytes 2 days after confluence were induced to differentiate in the presence of RM $(0-300 \mu \mathrm{g} / \mathrm{ml})$. At day 9 adipocytes RNA was isolated and RT-PCR for mRNA expression of (A) fatty acid synthase (FAS) and (B) acyl-coA synthetase (ACS1) was performed. Ratio is calculated against $\beta$-actin represented as arbitary units of integrated density value (IDV). Each experiment was repeated twice in duplicate and results are depicted as mean $\pm \mathrm{SD}$, statistical significance was calculated (letters that differ indicate, $p \leq 0.05$ ). 

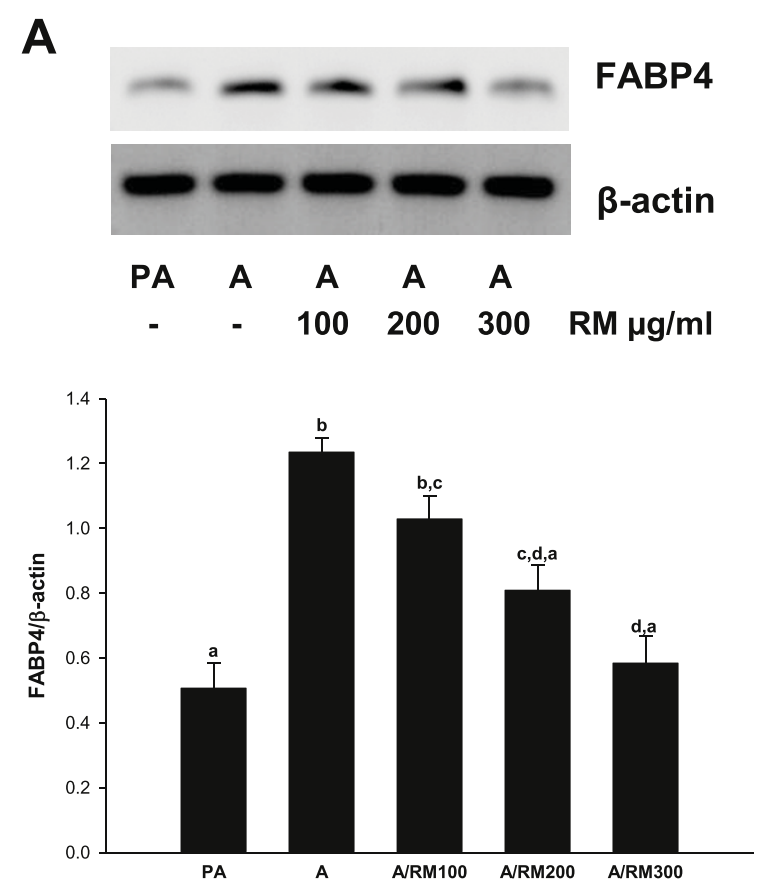

$\mathbf{B}$
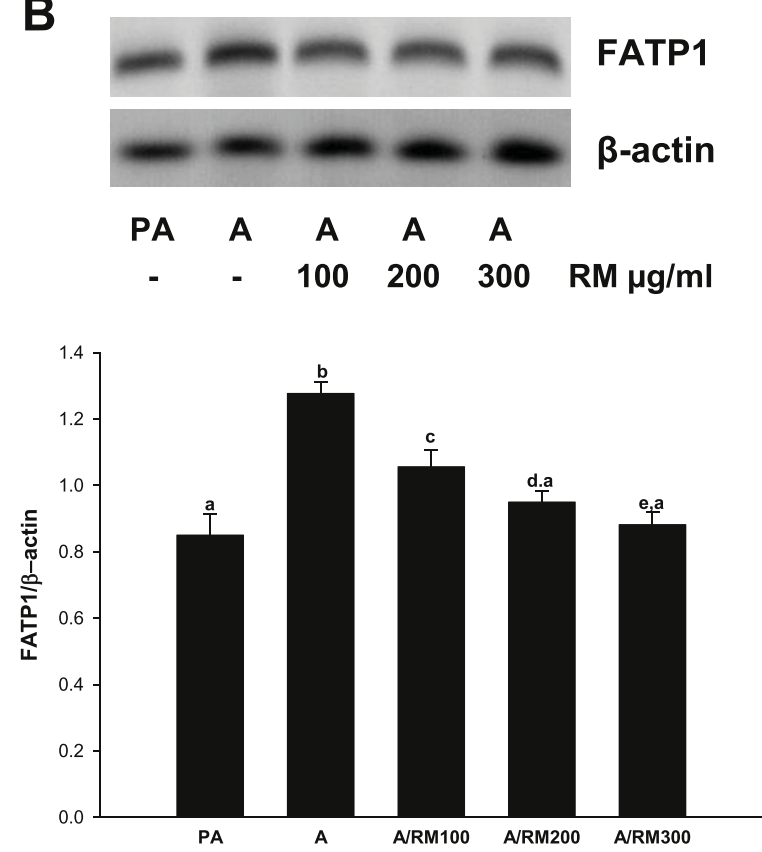

Figure 4 Effect of RM on FABP4 and FATP1. 3T3-L1 pre-adipocytes 2 days after confluence were induced to differentiate in the presence of RM $(0-300 \mu \mathrm{g} / \mathrm{ml})$. At day 9 adipocytes RNA was isolated and RT-PCR for mRNA expression of (A) fatty acid binding protein 4 (FABP4) and (B) fatty acid transport protein 1 (FATP1) was performed. Ratio is calculated against $\beta$-actin represented as arbitary units of integrated density value (IDV). Each experiment was repeated twice in duplicate and results are depicted as mean \pm SD, statistical significance was calculated (letters that differ indicate, $p \leq 0.05$ ). 


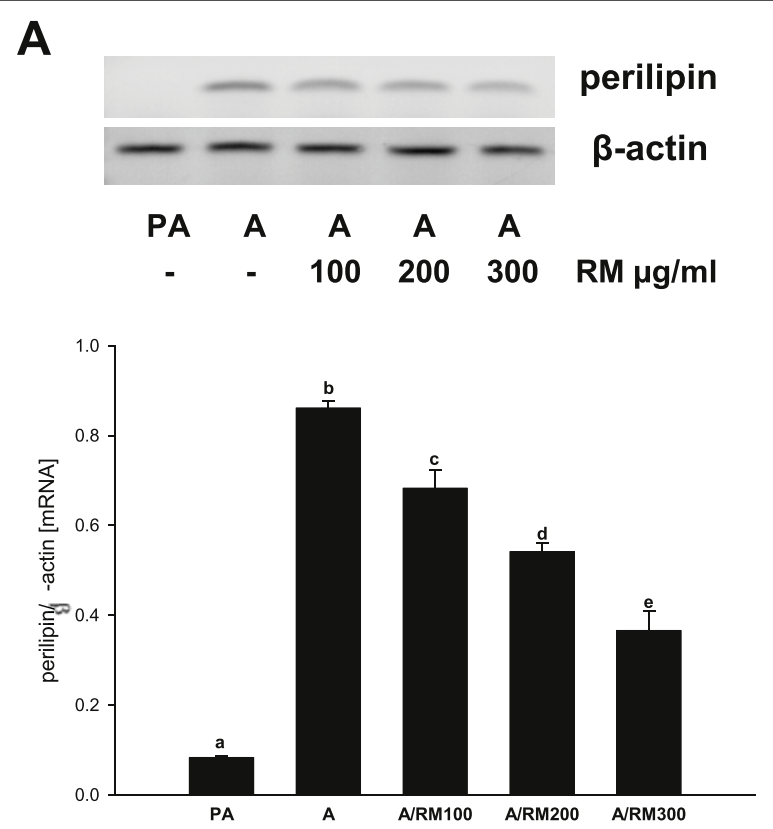

B

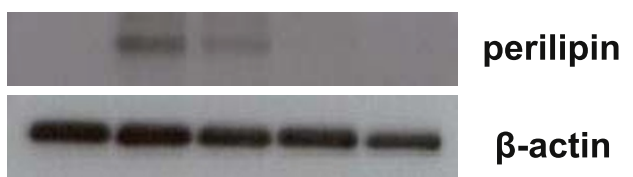

PA A A A A

- $\quad$ - $100200300 \quad \mathrm{RM} \mu \mathrm{g} / \mathrm{ml}$

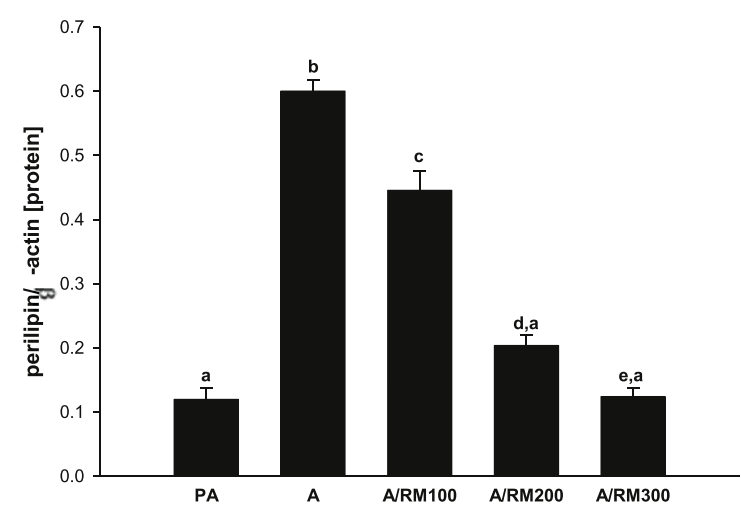

Figure 5 Effect of RM on mRNA levels of perilipin and protein expression for perilipin. 3T3-L1 pre-adipocytes 2 days after confluence were induced to differentiate in the presence of RM $(0-300 \mu \mathrm{g} / \mathrm{ml})$. At day 9 adipocytes RNA and proteins were isolated. (A) mRNA levels of perilipin were determined by RT-PCR and (B) protein expression of perilipin was determined by Western blot analysis. Each experiment was repeated thrice and results are depicted as mean $\pm S D$, statistical significance was calculated (letters that differ indicate, $p \leq 0.05$ ). 
A

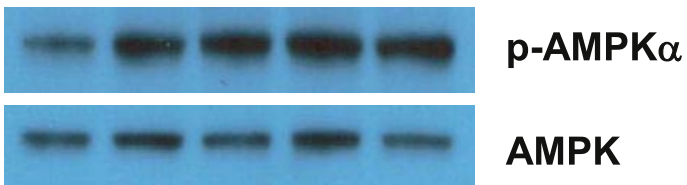

- $50100 \quad-\quad-\quad$ RM $[\mu \mathrm{g} / \mathrm{ml}]$

- $\quad$ - $\quad 100200 \quad$ Insulin [nM]

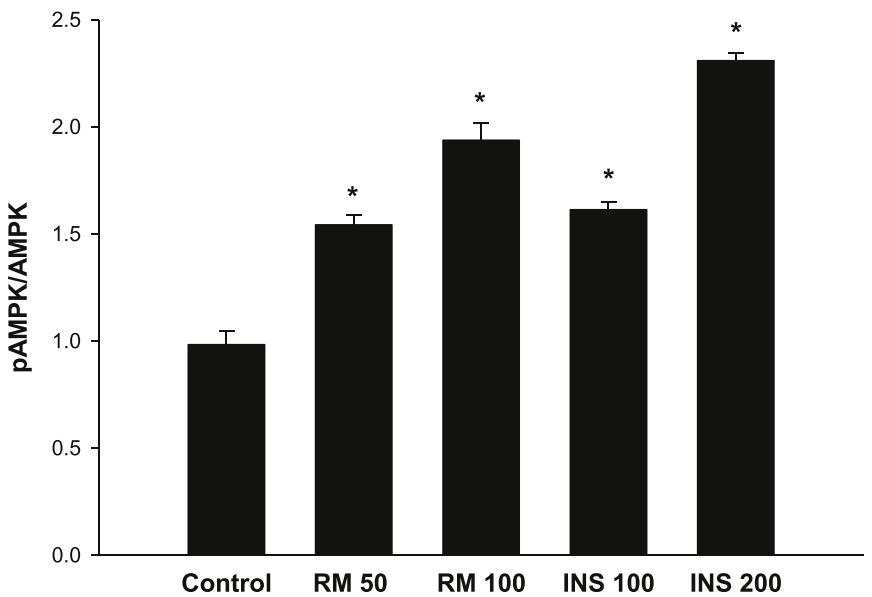

B

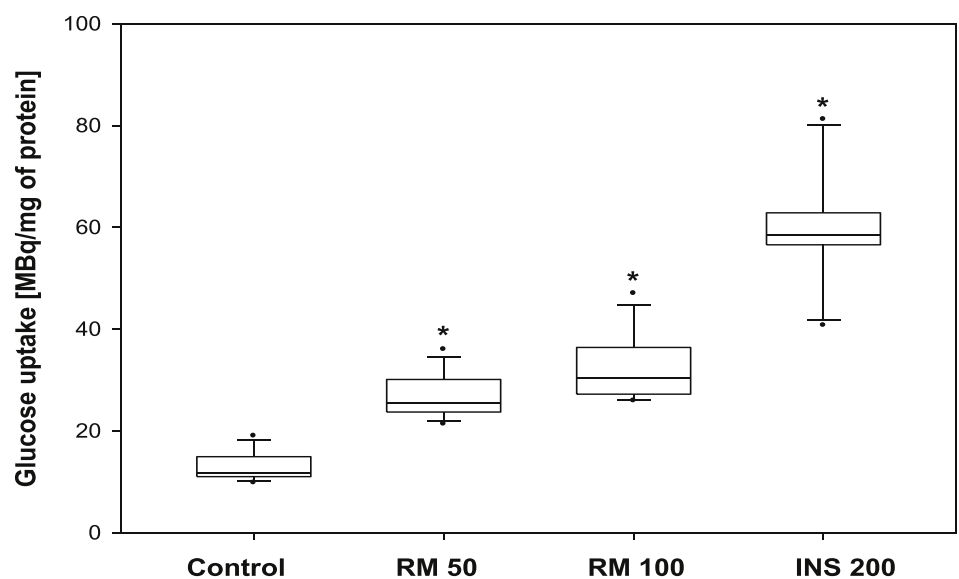

Figure 6 Effect of RM on AMPK and glucose uptake. 3T3-L1 pre-adipocytes 2 days after confluence were induced to differentiate. (A) 3T3-L1 adipocytes were treated with RM $(0,50,100 \mu \mathrm{g} / \mathrm{ml})$ or insulin $(100,200 \mathrm{nM})$ for 30 minutes and the expression of phopho-AMPK was detected by Western blot analysis as described in Materials and Methods. Immunoblots are representative of 3 independent experiments. Data represents mean \pm SD. ${ }^{*} p<0.05$ vs adipocyte control cells. (B) Glucose uptake was determined in 3T3-L1 adipocytes treated with RM $(0,50,100 \mu \mathrm{g} / \mathrm{ml})$ or insulin $(200 \mathrm{nM})$ as described in Materials and Methods. The results are mean $\pm S D(n=12),{ }^{*} p<0.05$ vs adipocyte control cells. 


\section{Discussion}

Obesity is increasing at an alarming rate in both the genders of all age groups around the world including United States [54]. According to the National Bureau of Economic Research report, the prevalence of obesity will rise to $40 \%$ in men and $43 \%$ in women by 2020 [55]. The major factors contributing to obesity are sedentary life style, inactivity, over eating and disturbances in the metabolism of fatty acids [56]. Various studies indicated that obese humans are at increased risk of developing diabetes, hypertension, cancer and atherosclerosis [57-59]. Thus, adipose tissue is recognized as a major secretory organ, releasing a variety of adipocytokines (e.g. adiponectin, leptin, resitin and others) which provide the link between obesity, insulin resistance and inflammatory disorders [60]. Therefore, new therapeutic agents that can regulate adipogenesis and glucose uptake can be employed to control obesity and type 2 diabetes.

In the present study, we evaluated the effect of ReishiMax (RM), dietary supplement containing triterpenes and polysaccharides isolated from medicinal mushroom Ganoderma lucidum, on adipocyte differentiation and glucose uptake in adipocytes. Here, we show that RM inhibited adipocyte differentiation/lipid accumulation through: a) the down-regulation of expression of transcription factors PPAR- $\gamma$, SREBP-1c and C/EBP- $\alpha$, and b) the suppression of expression of genes responsible for lipid synthesis (FAS, ACS1), lipid transport (FABP4, FATP1) and lipid storage (perillipin). However, we did not observe any changes in the expression of LPL, which expression is also controlled by PPAR- $\gamma$, SREBP$1 \mathrm{c}$ and $\mathrm{C} / \mathrm{EBP}-\alpha$. In agreement with our study, hydroxytorosol from olive oil inhibited lipid accumulation during adipocyte differentiation and inhibited all tested genes except LPL [61]. Nevertheless, others demonstrated down-regulation of LPL expression associated with the adipocyte differentiation [62,63]. These contradictory results might be explained by the use of different cell models: mouse 3T3-L1 (our study and [63]), C3H10 T1/2 [61] or human pre-adipocytes [62] or activation of $\beta$-catenin pathway [63]. Finally, RM activated AMPK resulting in the increased glucose uptake by adipocytes (Figure 7).

On the molecular level, C/EBP- $\alpha$, PPAR- $\gamma$ and SREBP$1 \mathrm{c}$ are induced during adipocyte differentiation [12]. Specifically, PPAR- $\gamma$ and SREBP-1c mRNAs start to be expressed at the very early/early stage (day 1-2 postconfluence) followed by the expression of C/EBP- $\alpha$ at the intermediate stage (day 4 post-confluence) [50]. These transcription factors further controls expression of adipocyte-specific genes (e.g. FAS, ACS1, FABP4, FATP1 and perilipin) at the late stage (day 5 post-confluence) leading to the fat droplet formation [64]. Therefore, the inhibition of PPAR- $\gamma$, SREBP-1c and C/EBP- $\alpha$, by $\mathrm{RM}$ at the early/intermediate stages results in the suppression of expression of adipocyte specific genes and lipid formation at the late stage of adipocyte differentiation.

The inhibition of adipogenesis by RM is in an agreement with recent studies demonstrating anti-adipogenic effects of white tea or bitter melon extracts or other

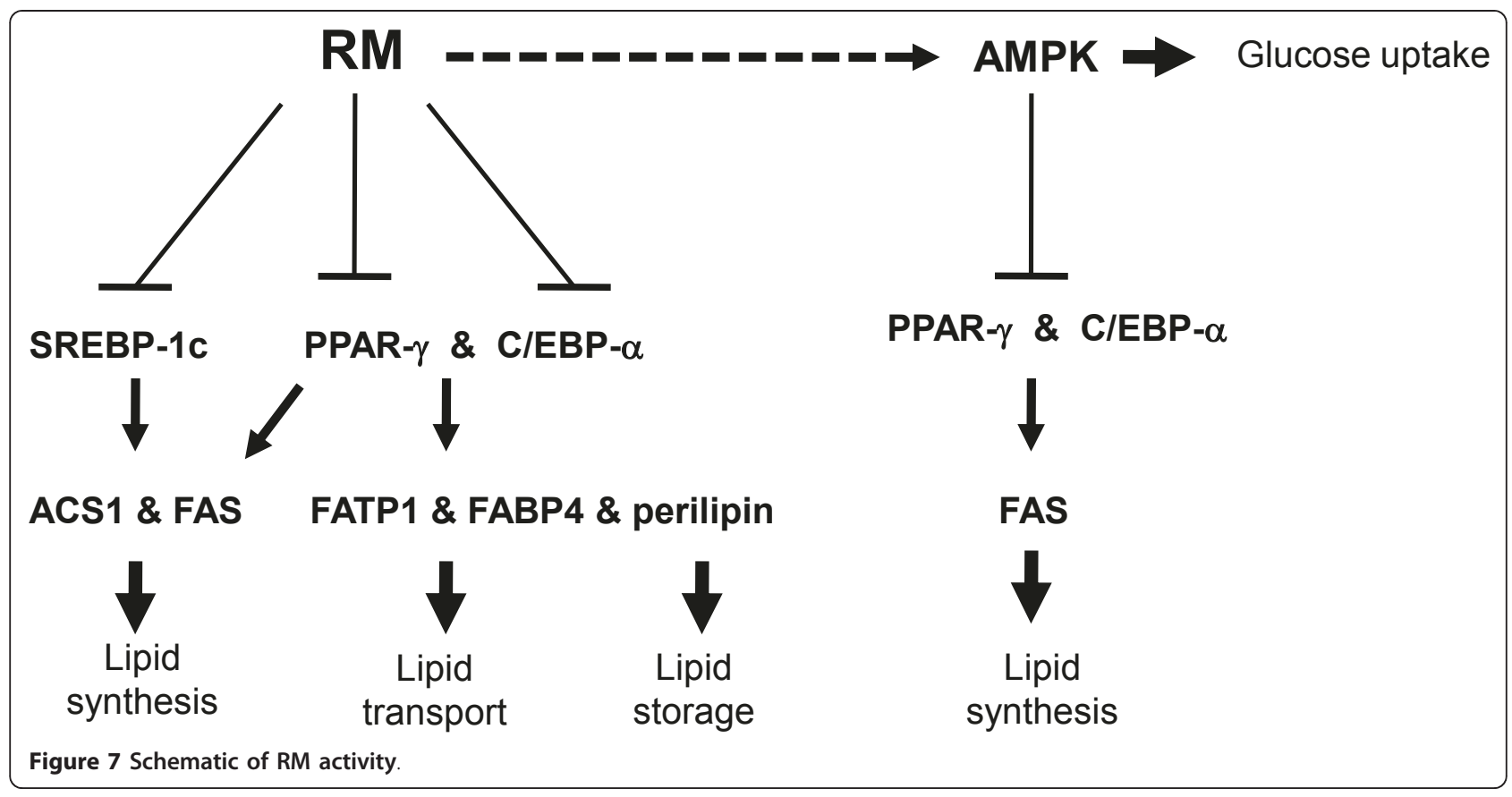


isolated phytochemicals [65-69]. Moreover, activation of AMPK was previously associated with the inhibition of adipocyte differentiation [70] or increased glucose uptake. Indeed, our data are in an agreement with recent reports by $\mathrm{Ha}$ et al $[71,72]$ demonstrating an increase of glucose uptake and inhibition of adipocyte differentiation through the activation of AMPK in 3T3L1 cells.

During the preparation of the present manuscript, Lee et al. demonstrated that some purified triterpenes from G. lucidum inhibit adipocyte differentiation, decrease lipid accumulation and down-regulate expression of PPAR- $\gamma$, SREBP-1c, C/EBP- $\alpha$, FAS and ACC [73-75]. Although the identification of biologically active components from G. lucidum is important for their possible therapeutic use, and more than 130 triterpenes have been isolated and new triterpenes continue to be identified [76], the yield of a majority of purified triterpenes is generally low. Therefore, the possible therapeutic use of purified triterpenes is currently limited. On the other hand, in our study we used standardized dietary supplement ReishiMax (RM) containing 6\% triterpenes and $13.5 \%$ polysaccharides. Moreover, we have previously identified some of the triterpenes in RM (e.g. ganoderic acids A, F, H, Mh, S, lucidenic acid B, D, D1, E1, L and methyl lucidenate G) [77], that can be used for the standardization of the active supplements or G. lucidum extracts. Our study is with agreement with previous study demonstrating stimulation of glucose uptake and activation of AMPK in rat muscle cells [78]. However, the authors used uncharacterized extract prepared from G. lucidum purchased from the Korean market [78]. On the other hand G. lucidum extract (GE), containing approximately $10 \%$ of ganoderic acid A, induced adipocyte differentiation and expression PPAR- $\gamma$ [79]. Although GE activated PPAR- $\gamma$, ganoderic acid A itself did not show any effect on PPAR- $\gamma$, suggesting that other compounds in GE are responsible for the GE activity [79]. Finally, standardized G. lucidum extract, containing polysaccharides, adenosine and ganoderic acid A, demonstrated mild anti-diabetic effects in a controlled human trial [80]. Since the presence and the amount of specific biologically active compounds in $G$. lucidum extracts depends on the source of G. lucidum, cultivation conditions, storage and extraction process [81], it is not surprising that extracts from the same mushroom could have different or opposite activities.

In summary, only standardized and characterized dietary supplements/extracts should be considered for the use in alternative medicine. Since the use of dietary supplements is not regulated and they are freely accessible, the proper characterization must be performed and associated with the specific activity.

\section{Conclusions}

In conclusion, the results of our study show that chemically characterized dietary supplement ReishiMax [RM], containing triterpenes and polysaccharides isolated from medicinal mushroom Ganoderma lucidum, inhibits the expression of key transcription factors and genes responsible for adipocyte differentiation, synthesis, transport and storage of lipids. In addition, RM activates AMPK and stimulates glucose uptake to the levels comparable to the insulin activity. Further preclinical studies evaluating RM activity in the management of obesity and type 2 diabetes are warranted.

\section{List of abbreviations}

ACS1: acyl-CoA synthetase-1; AMPK: AMP-activated protein kinase; C/EBP-a: CCAAT/enhancer binding protein-a; FABP4: fatty acid binding protein-4; FAS: fatty acid synthase; FATP1: fatty acid transport protein-1; LPL: lipoprotein lipase; PPAR-ү: peroxisome proliferator-activated receptor- - ; RM: ReishiMax; SREBP-1c: sterol regulatory element binding element protein-1c.

\section{Acknowledgements}

This study was supported by the Methodist Research Institute, Indiana University Health, Indianapolis and a grant from The Catherine Peachey Fund, Indianapolis, Indiana, USA to A. T-S.

\section{Author details}

'Cancer Research Laboratory, Methodist Research Institute, Indiana University Health, 1800 N Capitol Ave, E504, Indianapolis, IN 46202, USA. ²Department of Medicine, School of Medicine, Indiana University, Indianapolis, IN, USA. ${ }^{3}$ Indiana University Simon Cancer Center, Indianapolis, IN, 46202, USA.

\section{Authors' contributions}

DS designed research; AT-S and BL conducted research; AT-S, BL and DS analyzed data; AT-S and DS wrote the paper; DS had the primary responsibility for final content. All authors read and approved the final manuscript.

\section{Competing interests}

The authors declare that they have no competing interests.

Received: 5 August 2011 Accepted: 19 September 2011 Published: 19 September 2011

\section{References}

1. Smith PD, O'Halloran P, Hahn DL, Grasmick M, Radant L: Screening for obesity: clinical tools in evolution, a WREN study. Wisconsin Medical Journal 2010, 109(5):274-278.

2. Pi-Sunyer $X$ : The medical risks of obesity. Postgrad Med 2009, 121(6):21-33.

3. Shi Y, Burn P: Lipid metabolic enzymes: emerging drug targets for the treatment of obesity. Nat Rev Drug Discov 2004, 3(8):695-710.

4. McHugh MD: Fit or fat? A review of the debate on deaths attributable to obesity. Public Health Nurs 2006, 23(3):264-270.

5. Flegal KM, Carroll MD, Ogden CL, Curtin LR: Prevalence and trends in obesity among US adults, 1999-2008. JAMA 303(3):235-241.

6. Wellen KE, Hotamisligil GS: Inflammation, stress, and diabetes. J Clin Invest 2005, 115(5):1111-1119.

7. Berg AH, Scherer PE: Adipose tissue, inflammation, and cardiovascular disease. Circ Res 2005, 96(9):939-949.

8. Gimeno RE, Klaman LD: Adipose tissue as an active endocrine organ: recent advances. Curr Opin Pharmacol 2005, 5(2):122-128.

9. Frayn $\mathrm{KN}$ : Obesity and metabolic disease: is adipose tissue the culprit? Proc Nutr Soc 2005, 64(1):7-13.

10. Tilg H, Moschen AR: Adipocytokines: mediators linking adipose tissue, inflammation and immunity. Nat Rev Immunol 2006, 6(10):772-783. 
11. Schaffler A, Scholmerich J, Salzberger B: Adipose tissue as an immunological organ: Toll-like receptors, C1q/TNFs and CTRPs. Trends Immunol 2007, 28(9):393-399.

12. Gregoire FM, Smas CM, Sul HS: Understanding adipocyte differentiation. Physiol Rev 1998, 78(3):783-809.

13. MacDougald OA, Lane MD: Transcriptional regulation of gene expression during adipocyte differentiation. Annu Rev Biochem 1995, 64:345-373.

14. Rosen ED, Walkey CJ, Puigserver P, Spiegelman BM: Transcriptional regulation of adipogenesis. Genes Dev 2000, 14(11):1293-1307.

15. Spiegelman BM, Flier JS: Adipogenesis and obesity: rounding out the big picture. Cell 1996, 87(3):377-389.

16. Rangwala SM, Lazar MA: Transcriptional control of adipogenesis. Annu Rev Nutr 2000, 20:535-559.

17. Rosen ED, Spiegelman BM: Molecular regulation of adipogenesis. Annu Rev Cell Dev Biol 2000, 16:145-171

18. Kolehmainen M, Vidal H, Alhava E, Uusitupa MI: Sterol regulatory element binding protein 1c (SREBP-1c) expression in human obesity. Obes Res 2001, 9(11):706-712.

19. Farmer SR: Regulation of PPARgamma activity during adipogenesis. Int J Obes (Lond) 2005, 29(Suppl 1):S13-16.

20. Tontonoz P, Hu E, Graves RA, Budavari Al, Spiegelman BM: mPPAR gamma 2: tissue-specific regulator of an adipocyte enhancer. Genes Dev 1994, 8(10):1224-1234

21. Rosen ED, Sarraf P, Troy AE, Bradwin G, Moore K, Milstone DS, Spiegelman BM, Mortensen RM: PPAR gamma is required for the differentiation of adipose tissue in vivo and in vitro. Mol Cell 1999, 4(4):611-617.

22. Wu Z, Rosen ED, Brun R, Hauser S, Adelmant G, Troy AE, McKeon C, Darlington GJ, Spiegelman BM: Cross-regulation of C/EBP alpha and PPAR gamma controls the transcriptional pathway of adipogenesis and insulin sensitivity. Mol Cell 1999, 3(2):151-158.

23. Coppack SW: Pro-inflammatory cytokines and adipose tissue. Proc Nutr Soc 2001, 60(3):349-356.

24. Nawrocki AR, Scherer PE: Keynote review: the adipocyte as a drug discovery target. Drug Discov Today 2005, 10(18):1219-1230.

25. Wasan KM, Looije NA: Emerging pharmacological approaches to the treatment of obesity. J Pharm Pharm Sci 2005, 8(2):259-271.

26. Curtis R, Geesaman BJ, DiStefano PS: Ageing and metabolism: drug discovery opportunities. Nat Rev Drug Discov 2005, 4(7):569-580.

27. Kahn SE, Hull RL, Utzschneider KM: Mechanisms linking obesity to insulin resistance and type 2 diabetes. Nature 2006, 444(7121):840-846.

28. Moller DE: New drug targets for type 2 diabetes and the metabolic syndrome. Nature 2001, 414(6865):821-827.

29. Zhou G, Myers R, Li Y, Chen Y, Shen X, Fenyk-Melody J, Wu M, Ventre J, Doebber T, Fujii N, et al: Role of AMP-activated protein kinase in mechanism of metformin action. J Clin Invest 2001, 108(8):1167-1174.

30. Sliva D: Ganoderma lucidum (Reishi) in cancer treatment. Integr Cancer Ther 2003, 2(4):358-364.

31. Sliva D: Cellular and physiological effects of Ganoderma lucidum (Reishi). Mini Rev Med Chem 2004, 4(8):873-879.

32. Sliva D: Ganoderma lucidum in cancer research. Leuk Res 2006, 30(7):767-768.

33. Wasser S: Reishi (Ganoderma lucidum). Encyclopedia of Dietary Supplements 2005, 603-622

34. Thyagarajan A, Jiang J, Hopf A, Adamec J, Sliva D: Inhibition of oxidative stress-induced invasiveness of cancer cells by Ganoderma lucidum is mediated through the suppression of interleukin-8 secretion. Int J Mol Med 2006, 18(4):657-664.

35. Thyagarajan A, Zhu J, Sliva D: Combined effect of green tea and Ganoderma lucidum on invasive behavior of breast cancer cells. Int J Oncol 2007, 30(4):963-969.

36. Jiang J, Slivova V, Sliva D: Ganoderma lucidum inhibits proliferation of human breast cancer cells by down-regulation of estrogen receptor and NF-kappaB signaling. Int J Oncol 2006, 29(3):695-703.

37. Jiang J, Slivova V, Harvey K, Valachovicova T, Sliva D: Ganoderma lucidum suppresses growth of breast cancer cells through the inhibition of Akt/ NF-kappaB signaling. Nutr Cancer 2004, 49(2):209-216.

38. Jiang J, Slivova V, Valachovicova T, Harvey K, Sliva D: Ganoderma lucidum inhibits proliferation and induces apoptosis in human prostate cancer cells PC-3. Int J Oncol 2004, 24(5):1093-1099.
39. Stanley G, Harvey K, Slivova V, Jiang J, Sliva D: Ganoderma lucidum suppresses angiogenesis through the inhibition of secretion of VEGF and TGF-beta1 from prostate cancer cells. Biochem Biophys Res Commun 2005, 330(1):46-52.

40. Dudhgaonkar S, Thyagarajan A, Sliva D: Suppression of the inflammatory response by triterpenes isolated from the mushroom Ganoderma lucidum. Int Immunopharmacol 2009, 9(11):1272-1280.

41. Liu F, Kim J, Li Y, Liu X, Li J, Chen X: An extract of Lagerstroemia speciosa L. has insulin-like glucose uptake-stimulatory and adipocyte differentiation-inhibitory activities in 3T3-L1 cells. J Nutr 2001, 131(9):2242-2247.

42. Giri S, Rattan R, Haq E, Khan M, Yasmin R, Won JS, Key L, Singh AK, Singh I: AICAR inhibits adipocyte differentiation in $3 \mathrm{~T} 3 \mathrm{~L} 1$ and restores metabolic alterations in diet-induced obesity mice model. Nutr Metab (Lond) 2006, 3:31.

43. Shimabukuro M, Koyama K, Chen G, Wang MY, Trieu F, Lee Y, Newgard CB, Unger $\mathrm{RH}$ : Direct antidiabetic effect of leptin through triglyceride depletion of tissues. Proc Natl Acad Sci USA 1997, 94(9):4637-4641.

44. Chakrabarti P, Kandror KV: FoxO1 controls insulin-dependent adipose triglyceride lipase (ATGL) expression and lipolysis in adipocytes. J Biol Chem 2009, 284(20):13296-13300.

45. Sakoda $H$, Ogihara T, Anai M, Funaki M, Inukai K, Katagiri H, Fukushima $Y$, Onishi $Y$, Ono H, Yazaki $Y$, et al: No correlation of plasma cell 1 overexpression with insulin resistance in diabetic rats and 3T3-L1 adipocytes. Diabetes 1999, 48(7):1365-1371.

46. Garcia de Herreros A, Birnbaum MJ: The acquisition of increased insulinresponsive hexose transport in 3T3-L1 adipocytes correlates with expression of a novel transporter gene. J Biol Chem 1989, 264(33):19994-19999.

47. Thyagarajan A, Jedinak A, Nguyen H, Terry C, Baldridge LA, Jiang J, Sliva D: Triterpenes From Ganoderma Lucidum Induce Autophagy in Colon Cancer Through the Inhibition of p38 Mitogen-Activated Kinase (p38 MAPK). Nutr Cancer 2010, 62(5):630-640.

48. Lafontan M: Advances in adipose tissue metabolism. Int J Obes (Lond) 2008, 32(Suppl 7):S39-51.

49. Auwerx J, Leroy P, Schoonjans K: Lipoprotein lipase: recent contributions from molecular biology. Crit Rev Clin Lab Sci 1992, 29(3-4):243-268.

50. Kim JB, Spiegelman BM: ADD1/SREBP1 promotes adipocyte differentiation and gene expression linked to fatty acid metabolism. Genes Dev 1996, 10(9):1096-1107.

51. Zhang BB, Zhou G, Li C: AMPK: an emerging drug target for diabetes and the metabolic syndrome. Cell Metab 2009, 9(5):407-416.

52. Carling D: The AMP-activated protein kinase cascade-a unifying system for energy control. Trends Biochem Sci 2004, 29(1):18-24.

53. Hardie DG: AMP-activated protein kinase as a drug target. Annu Rev Pharmacol Toxicol 2007, 47:185-210.

54. CDC: Obesity Trends Among U.S. Adults Between 1985 and 2009. 2009 [http://www.cdc.gov/obesity/data/trends.html].

55. Research NBoE: The Increasing Prevalence of Obesity 2011 [http://www.nber. org/digest/jul08/w13181.html].

56. Mokdad AH, Serdula MK, Dietz WH, Bowman BA, Marks JS, Koplan JP: The spread of the obesity epidemic in the United States, 1991-1998. JAMA 1999, 282(16):1519-1522.

57. Okosun IS, Chandra KM, Choi S, Christman J, Dever GE, Prewitt TE: Hypertension and type 2 diabetes comorbidity in adults in the United States: risk of overall and regional adiposity. Obes Res 2001, 9(1):1-9.

58. Calle EE, Kaaks R: Overweight, obesity and cancer: epidemiological evidence and proposed mechanisms. Nat Rev Cancer 2004, 4(8):579-591.

59. Rajala MW, Scherer PE: Minireview: The adipocyte-at the crossroads of energy homeostasis, inflammation, and atherosclerosis. Endocrinology 2003, 144(9):3765-3773.

60. Fantuzzi G: Adipose tissue, adipokines, and inflammation. J Allergy Clin Immunol 2005, 115(5):911-919, quiz 920

61. Warnke I, Goralczyk R, Fuhrer E, Schwager J: Dietary constituents reduce lipid accumulation in murine $\mathrm{C} 3 \mathrm{H} 10 \mathrm{~T} 1 / 2$ adipocytes: A novel fluorescent method to quantify fat droplets. Nutr Metab (Lond) 2011, 8(1):30.

62. Díaz-Delfín J, del Mar Gutiérrez M, Gallego-Escuredo JM, Domingo JC, Gracia MMateo, Villarroya F, Domingo P, Giralt M: Effects of nevirapine and efavirenz on human adipocyte differentiation, gene expression, and release of adipokines and cytokines. Antiviral Res 2011, 91(2):112-9. 
63. Lee $H$, Kang R, Bae $S$, Yoon Y: AICAR, an activator of AMPK, inhibits adipogenesis via the WNT/ $\beta$-catenin pathway in 3T3-L1 adipocytes. Int J Mol Med 2011, 28(1):65-71.

64. Ntambi JM, Young-Cheul K: Adipocyte differentiation and gene expression. J Nutr 2000, 130(12):3122S-3126S.

65. Hwang JT, Park IJ, Shin JI, Lee YK, Lee SK, Baik HW, Ha J, Park OJ: Genistein, EGCG, and capsaicin inhibit adipocyte differentiation process via activating AMP-activated protein kinase. Biochem Biophys Res Commun 2005, 338(2):694-699.

66. Sohle J, Knott A, Holtzmann U, Siegner R, Gronniger E, Schepky A, Gallinat S, Wenck H, Stab F, Winnefeld M: White Tea extract induces lipolytic activity and inhibits adipogenesis in human subcutaneous (pre)adipocytes. Nutr Metab (Lond) 2009, 6:20.

67. Nerurkar PV, Lee YK, Nerurkar VR: Momordica charantia (bitter melon) inhibits primary human adipocyte differentiation by modulating adipogenic genes. BMC Complement Altern Med 2010, 10:34.

68. Lee $H$, Kang $R$, Yoon Y: Shikonin inhibits fat accumulation in 3T3-L1 adipocytes. Phytother Res 2010, 24(3):344-351.

69. Olholm J, Paulsen SK, Cullberg KB, Richelsen B, Pedersen SB: Antiinflammatory effect of resveratrol on adipokine expression and secretion in human adipose tissue explants. Int J Obes (Lond) 2010, 34(10):1546-1553.

70. Habinowski SA, Witters LA: The effects of AICAR on adipocyte differentiation of 3T3-L1 cells. Biochem Biophys Res Commun 2001, 286(5):852-856.

71. Ha do T, Trung TN, Phuong TT, Yim N, Chen QC, Bae K: The selected flavonol glycoside derived from Sophorae Flos improves glucose uptake and inhibits adipocyte differentiation via activation AMPK in 3T3-L1 cells. Bioorg Med Chem Lett 2010, 20(20):6076-6081.

72. Ha do T, Nam Trung T, Bich Thu N, Van On T, Hai Nam N, Van Men C, Thi Phuong T, Bae K: Adlay seed extract (Coix lachryma-jobi L.) decreased adipocyte differentiation and increased glucose uptake in 3T3-L1 cells. J Med Food 2010, 13(6):1331-1339.

73. Lee I, Seo J, Kim J, Kim H, Youn U, Lee J, Jung H, Na M, Hattori M, Min B, et al: Lanostane triterpenes from the fruiting bodies of Ganoderma lucidum and their inhibitory effects on adipocyte differentiation in 3T3L1 Cells. J Nat Prod 2010, 73(2):172-176.

74. Lee I, Kim H, Youn U, Kim J, Min B, Jung H, Na M, Hattori M, Bae K: Effect of lanostane triterpenes from the fruiting bodies of Ganoderma lucidum on adipocyte differentiation in 3T3-L1 cells. Planta Med 2010, 76(14):1558-1563.

75. Lee I, Kim J, Ryoo I, Kim Y, Choo S, Yoo I, Min B, Na M, Hattori M, Bae K: Lanostane triterpenes from Ganoderma lucidum suppress the adipogenesis in 3T3-L1 cells through down-regulation of SREBP-1C. Bioorg Med Chem Lett 2010, 20(18):5577-5581.

76. Sliva D: Medicinal potential of Ganoderma lucidum. In Applied Mycology. Edited by: Rai M. Bridge, PD: CAB International; 2009:173-196.

77. Adamec J, Jannasch A, Dudhgaonkar S, Jedinak A, Sedlak M, Sliva D: Development of a new method for improved identification and relative quantification of unknown metabolites in complex samples: determination of a triterpenoid metabolic fingerprint for the in situ characterization of Ganoderma bioactive compounds. J Sep Sci 2009, 32(23-24):4052-4058.

78. Jung KH, Ha E, Kim MJ, Uhm YK, Kim HK, Hong SJ, Chung JH, Yim SV: Ganoderma lucidum extract stimulates glucose uptake in L6 rat skeletal muscle cells. Acta Biochim Pol 2006, 53(3):597-601.

79. Shimojo Y, Kosaka K, Shirasawa T: Effect of Ganoderma lucidum extract on adipocyte differentiation and adiponectin gene expression in the murine pre-adipocyte cell line, 3T3-L1. Phytother Res 2010, 25(2):202-207.

80. Chu TT, Benzie IF, Lam CW, Fok BS, Lee KK, Tomlinson B: Study of potential cardioprotective effects of Ganoderma lucidum (Lingzhi): results of a controlled human intervention trial. Br J Nutr 2011, 1-11.

81. Sliva D, Sedlak M, Slivova V, Valachovicova T, Lloyd FP, Ho NW: Biologic activity of spores and dried powder from Ganoderma lucidum for the inhibition of highly invasive human breast and prostate cancer cells. $J$ Altern Complement Med 2003, 9(4):491-497.

\section{Pre-publication history}

The pre-publication history for this paper can be accessed here:

http://www.biomedcentral.com/1472-6882/11/74/prepub

\section{doi:10.1186/1472-6882-11-74}

Cite this article as: Thyagarajan-Sahu et al:: ReishiMax, mushroom based dietary supplement, inhibits adipocyte differentiation, stimulates glucose uptake and activates AMPK. BMC Complementary and Alternative Medicine 2011 11:74.

\section{Submit your next manuscript to BioMed Central and take full advantage of:}

- Convenient online submission

- Thorough peer review

- No space constraints or color figure charges

- Immediate publication on acceptance

- Inclusion in PubMed, CAS, Scopus and Google Scholar

- Research which is freely available for redistribution

Submit your manuscript at www.biomedcentral.com/submit
C Biomed Central 